\title{
COMMITTEE POLICY MAKING IN THE HOUSE: COMPARING THE AGRICULTURE AND JUDICIARY COMMITTEES
}

\author{
Robert E. Dewhirst \\ (Northwest Missouri State University)
}

\section{Introduction}

This paper explores whether committees or their subcommittees dominate policy making in the standing committees of the House of Representatives. Such a research question falls within a tradition of inquiry initiated more than a century ago when Woodrow Wilson argued that Congressional government was ultimately committee government. However, more recent scholars have begun speculating that committees have declined in influence in favor of subcommittees. The most extreme dimension of this viewpoint has even maintained that congressional government has become subcommittee government.

This research effort focuses on legislation presented to the House by that body's Judiciary Committee during the 99th Congress and Agriculture Committee during the 95th and 98th Congresses. These committees and years were selected first because they represent a few of the extremely rare opportunities of data available to observers for study. Moreover, acquiring such information is an attempt to overcome serious obstacles in this arena identified by Steven Smith and Christopher Deering. They note that it would be ideal if one could trace passage of a bill from subcommittees through their full committee to the House to compare the policy making roles of the two entities. However, they report that "unfortunately," access to House committee records makes such a worthy task "very difficult or impossible" (Smith and Deering, 1984, p. 163). The goal here is to at least partially overcome these serious research obstacles by systematically analyzing the limited data which could be found.

The two committees also were selected because of the representativeness of the panels as ideal types of distinctive House committees. Richard Fenno, in his classic study of congressional committees, argued that committees differ systematically in accord with such variables as member goals, environmental constraints, and 
decision making processes (Fenno, 1973) of the classification scheme used subsequently by many congressional scholars, the House Agriculture Committee has been considered a prime example of a constituency committee while the House Judiciary Committee has been clearly thought of as a policy committee. Finally, in addition to their many differences, the committees were attractive for this study because the text of bills written by them was available in government documents. Few House committees provide such information comprehensively in print which can be studied by those distant from Washington, D.C. Otherwise, the content of legislation reported by subcommittees to their full committees is locked away in committee files and stored in the National Archives, unavailable for scholarly examination for several decades (Smith and Deering, 1984, p. 163).

Growing interest among scholars in the possible redistribution of the balance of power between committees and subcommittees stems from anticipated changes in congressional policy making behavior brought about by reforms in the House in 1974 and in the Senate three years later. The series of reforms in the House, termed by some as "The Subcommittee Bill of Rights," were adopted by the Democratic Caucus in an attempt to do a number of things, one of which was to reduce the power of committee chairmen in relation to their subcommittees. Overall, the reforms were thought to decentralize power in the House by increasing the number of subcommittees, their staffs, and their power. Ultimately, such changes led some observers to speculate openly that Wilson's long-standing dictum of congressional government really being committee government was no longer true. Hence, some later-day analysts have come to argue that congressional government has become subcommittee government.

\section{Literature Review}

Committee/Subcommittee Relations. So, to what extent has Congress, especially the House of Representatives, really changed? An array of viewpoints have been suggested about whether committees or subcommittees dominate policy making in the House. One position is that subcommittees have been more influential. Lawrence Dodd and Richard Schott have maintained that subcommittee government had been institutionalized in Congress by the mid-1970's. Roger Davidson also makes a similar argument. "Subcommittee government exists in Congress," he asserts. Davidson maintains that subcommittees have 
become the "leading initiators and drafters of legislative measures and reports" while tending to "frame the issues and do the initial specifying of details" (Davidson, 1981, pp. 114, 117). Morever, in carrying out these duties the busier subcommittees have grown to resemble full committees in their heavy workload.

Conversely, Davidson argues that full committees have come to play one of three roles in relation to their respective subcommittees: "they may deliberate de novo on legislation, they may review their subcommittees' decision, or they may simply pass the subcommittees' products along to the full chamber"' (Davidson, 1981, p. 114).

Lawrence Dodd and Bruce Oppenheimer agree with Davidson's assertion of subcommittee government. "By the late 1970's policy making activity was increasingly the providence of the standing subcommittees," they argue. "With the rise of subcommittee government, committee decision making responsibility flowed increasingly to subcommittees." They viewed standing committees as becoming "appeals courts" for dissatisfied members to attempt to win battles lost in subcommittee struggles (Dodd and Oppenheimer, 1985, pp. 43-6).

On the other hand, Steven Smith and Christopher Deering are more restrained in assessing the balance of power between subcommittees and committees. They maintain their findings reveal that ". .. the most frequent House decision making pattern is one of mixed full committee and subcommittee participation." They conclude that the House "clearly has moved toward subcommittee government" but caution that committee policy making has been characterized by "a mixed pattern of subcommittee and full committee involvement" (Smith and Deering, 1984, pp. 133-4). In a later study the authors add that while subcommittees have been playing an increasingly important role, "they do not govern the institution as completely as committees did at the height of their power' (Deering and Smith, 1985, p. 207).

Finally, Richard Hall and C. Lawrence Evans have a slightly different perspective. They have found that the subcommittee emembership self-selection process initiated by the reforms in general have tended to help subcommittee members prevail in decision making by the full committee. This was due, at least in part, to the subcommittee members' greater interest, motivation, and knowledge in their groups' legislation when it was presented to the full committee for markup. This factor often has helped subcommittee members take the lead during markup sessions in the full committee. However, the full committee was found to dominate policy making in cases where its members also felt 
strongly about a bill (Hall and Evans, 1985).

Judiciary Committee Politics in the House. Politics in the House Judiciary Committee have evolved greatly since the days before the Congressional reforms in the mid-1970's. Previously, the committee was a prized assignment sought eagerly by members wanting to protect and promote the civil liberties and rights of citizens. The committee's televised hearings on considering articles of impeachment of President Richard Nixon further publicized the work of the panel.

However, the Judiciary Committee now often must work to attract members. For example, since the 97th Congress Democrats may join the panel as an assignment beyond their normal two committee limit. At least two major reasons have surfaced for the dramatic collapse in appeal of this once-prominent committee. First, the committee has jurisdiction over five volatile conservative social issues-abortion, school prayer, school busing, gun control, and the death penalty - any one of which can attract an outcry of constituent opposition for a perceived "wrong" vote. In addition, the committee authorizes few federal funds and attracts little in the way of campaign donations.

In response to this environment, the committee's chair during this entire period, Rep. Peter W. Rodino, Jr., stacked the panel with Democrats sharing his basic liberal views on civil and constitutional rights. This enabled them to bury legislation hostile to their views. By the 1980's, critics dubbed the committee the congressional "Bermuda Triangle" in tribute to the many conservative social measures which were introduced into the panel each term only to be never heard from again (Davidson and Oleszek, 1985, pp. 214, 221).

Agriculture Committee Politics in the House. Agriculture politics in the House of Representatives have traditionally been characterized by large scale vote trading featuring hefty and potentially fragile coalition building. Concerning floor votes, the continuing decline of population in farm districts has necessitated the establishment of a coalition with non-agricultural interests to assure passage of farm legislation. Farm representatives successfully packaged logrolling arrangements with urban Congressmen seeking approval of such measures as minimum wage and food stamps legislation (Peters, 1978).

Likewise, politics within the House Agriculture Committee have traditionally been characterized by a coalition of representatives supporting the array of commodities produced most predominantly in American agriculture. Thus, representatives from areas producing such commodities as tobacco, cotton, feed grains, etc., maneuver for seats on 
the committee to protect and promote "their" folks back home. Not surprisingly, this committee has been labeled as "the classic constituency committee," those committees members join to promote the well-being of their districts (Smith and Deering, 1984, p. 105). Traditionally, this characteristic of its membership has led the committee to have a regional bias of representation from primarily southern but also midwestern states (Peters, 1978 and 1982, and Jones, 1969).

Meanwhile, Glenn and Suzanne Parker found that constituency interests, ideology, and party to be important environmental influences on the House Agriculture Committee. Their analysis identified four factions on the committee during the years 1973-76: northern and southern Democrats, the Republicans as one faction, and two members which formed a "factional doublet" (Parker and Parker, 1985, pp. 15966).

Finally, the content of agriculture policy has been based largely on the passage of a farm bill with "sunset" provisions calling for renewal every four or five years. The major mechanisms of farm policies, such as price supports or land-diversion programs, have been designed traditionally to help stabilize and supplement farmer incomes subject to the frequent whims of such volatile interlopers as bad weather or declining market prices (Peters, 1978 and 1982).

\section{Methodology}

Previous scholars have sought to measure the extent of subcommittee government in the House by examining subcommittee activities and resources. Perhaps most notably, Deering and Smith divided these factors into four areas: the amount of legislation reported to the floor that was considered by subcommittees, the number of meetings and hearings held by subcommittees, patterns of bill management, and the level of subcommittee staff resources (Deering and Smitn, 1985, p. i92).

The approach which will be used here seeks a possibly more direct route by examining the content of legislation itsin in a manner similar to studies done by both Smith and Deering and Hall and Evans. This examination is based upon an analysis of the text of bills marked up by the House Agriculture Committee in the 95th (1977-1978) and 98th (1983-1984) Congresses and the House Judiciary Committee in the 99th (1985-1986) Congress. Information on the Agriculture Committee's activities was culled from the text of bills published in the Minutes 
of the Business Meetings and Hearings of the Committee on Agriculture, House of Representatives. Information for the Judiciary Committee was gathered from the published versions of all "clean bills" reported out by the panel's seven subcommittees. Only clean bills were analyzed because only they presented a clear picture (via a clean bill coming from a subcommittee) of the subcommittee bill against which the full committee's product reported to the Rules Committee) could be compared. The Agriculture Committee is the only House panel to publish its mark-up changes in its minutes. The Judiciary Committee is the only panel in which its bills marked up by subcommittee are regularly (but, alas, not every bill) renumbered as clean bills, thus leaving a clear fingerprint of the subcommittee's work.

Each bill reported out by one of the standing subcommittees to either full committee was coded in the following manner (inspired in part by the Davidson roles mentioned earlier) in terms of full committee action: 1) reported out with no or only minor (such as stylistic) changes; 2) reported out with changes which altered the bill in a notable (such as a 15 percent increase in funding) manner; 3) reported out with major changes which significantly altered the basic thrust of the legislation (such as removing an integral part of the proposed program); and 4) bill fails to pass the committee.

In sum, one overall goal of this study is to discover the policy making roles played by subcommittees in the House when compared with their full committee. Indeed, does the Wilson thesis need to be modified? Is there subcommittee government in the House? Finally, does the type of committee affect the policy making balance between the full panel and its subcommittees? Indeed, Smith and Deering argue that the nature of the committee does make a difference, ". . . if subcommittee government is at work, it is more likely to appear on district-oriented panels than on policy-oriented committees" (Smith and Deering, 1984, p. 198). Hence, the expectations here should be that the Agriculture Committee would be much more likely to be affected by tendencies toward subcommittee government than would be the Judiciary Committee.

\section{Findings}

Agriculture Committee in the 95th Congress. Overall, Table 1 suggests a rather restrained picture of subcommittee government as painted by both Smith and Deering, and Hall and Evans. On one hand, the 
95th Congress, convening a few years after the passage of the subcommittee bill of rights, still reveals some policy making strength by full committees. The table here reports that 38 percent (31 of 82 ) of the bills considered by the House Agriculture Committee were handled by the full committee. On the other hand, almost 28 percent (23 of 82 ) were assigned to the first category — where bills passed the full committee with little or no change.

\section{TABLE 1}

\section{House Agriculture Committee Action Taken on Bills Reported to it by its Ten Subcommittees, 95th Congress}

\section{Action Taken}

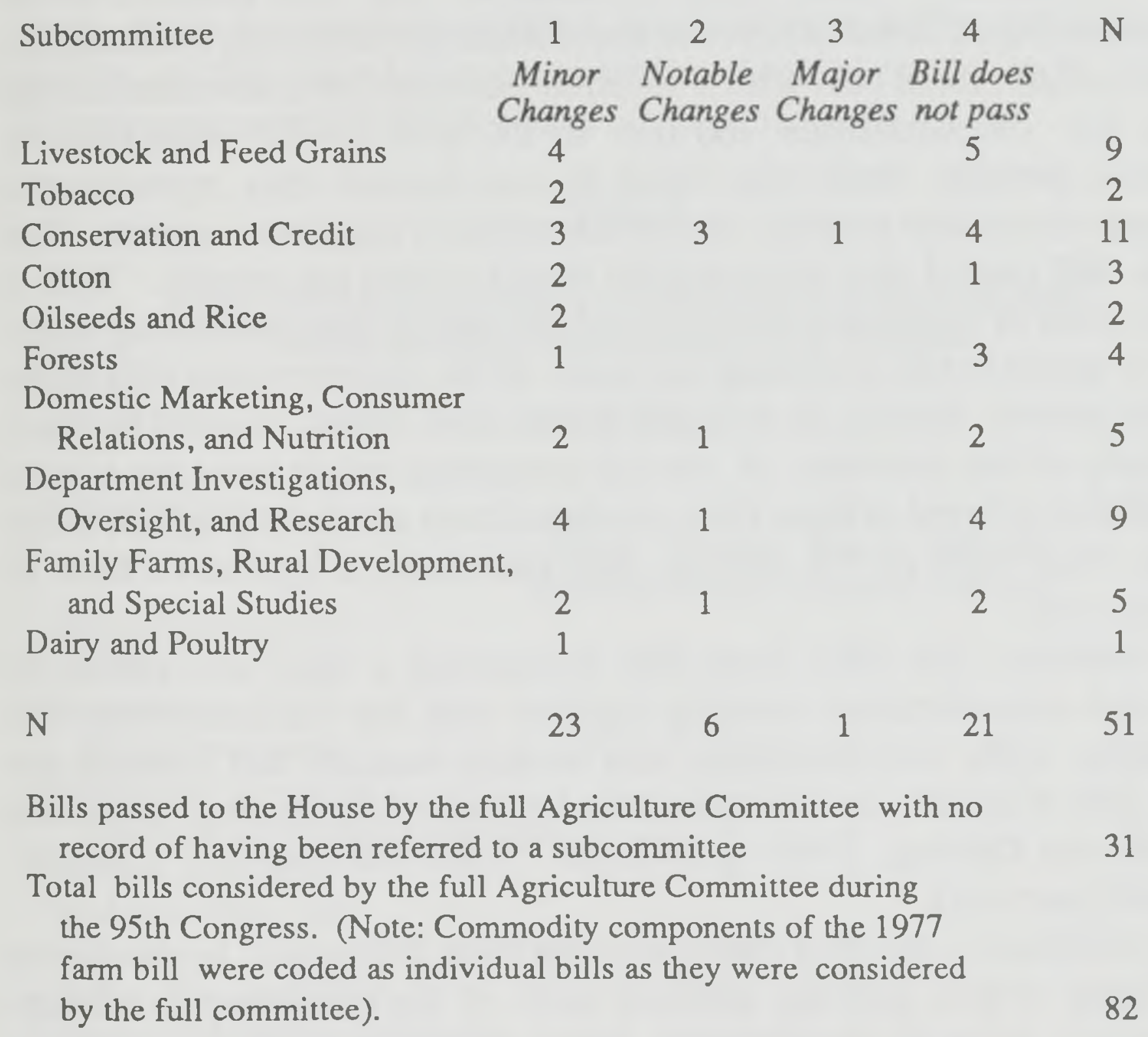

1. Reported out with no or only minor (such as stylistic)changes.

2. Reported out with changes which altered the bill in a notable manner.

3. Reported out with major changes which significantly altered basic thrust of the bill. 4. No record of the bill passing the committee.

Source: Minuses of the Business Meetings and Hearings of the Committee on Agriculiure, House of Representatives, 95 th Congress, U.S. Govermment Printing Office, Washington, D.C., 1977-9, Four Volumes. 
Similarly, the somewhat mixed picture continues when the three remaining categories are examined. First, only seven bills were found to be in the "notable" and "major change" categories. This suggests that the full committee was rather restrained in looking over the collective shoulders of the subcommittees. Moreover, in the final category, bills dying in committee, reported a total of 21 , slightly fewer bills than those in the "minor change" category. However, only one of these was found to have been recorded as being rejected in a vote of the full committee. In addition, two other bills were returned to subcommittees for additional work. One of these was later reported back to the full committee and was ultimately passed as a category one bill (and, hence not finally recorded as a category four bill).

Yet what happened to the remaining bills which failed to pass the full committee? While such information was not available in the documents used in this study, one could make the following speculations. First, perhaps these bills which failed to pass the full committee arrived from the subcommittees too late in the term for full consideration. Second, perhaps those bills failed to pass because they represented a comparatively low priority on the committee's legislative agenda. The Farm Bill passed that year naturally would receive top priority. With a likely rush of legislation lining up behind such a time-consuming major bill it would not be surprising that some of the less important bills might not be passed. Finally, as Hall and Evans have noted, it could be that a majority of the members of the full committee might not want to pass some bills referred to them from subcommittees and quietly agreed to not bring those bills up for markup, thus exercising a legislative form of pocket veto.

Finally, the 1977 Farm Bill represented a blend of efforts by selected subcommittees working together with the full committee. For example, while subcommittees held markup sessions and reported out their title of the bill, the full committee held all of the hearings on the bill (Smith and Deering, 1984, p. 142, and "Farm Bill Cleared," Congressional Quarterly).

Ultimately, the final character of the Farm Bill passed by the House depended in part upon the political skill of the committee chair, Rep. Thomas S. Foley (D-Washington). Foley had replaced the once-influential chair, W.R. "Bob" Poage (D-Texas), who had been removed by a vote of the House Democratic Caucus not long after the reforms had been adopted. Confronted for the first time with the task of shepherding a farm bill through both the committee and the House, Foley responded by assuring his colleagues that the subsidy programs would be "as large as 
the administration and the House would permit, an aspiration appreciated by most of his committee colleagues." Foley achieved committee approval by having the respective commodity subcommittees be responsible for marking up "their" sections of the bill and then having them all work together when meeting with the full committee. "When each section was introduced and debated in the full committee markup sessions, rules of equity and fair share for commodities prevailed"' (Smith and Deering, 1984, p. 142).

Finally, while it is not directly pertient to the goals of this study, it is interesting to note the differences of legislative activity from among the subcommittees. Three of the subcommittees were much more active than the others in producing legislation: Conservation and Credit (11 bills), Livestock and Feed Grains (9 bills), and Department Investigations, Oversight, and Rearch (9 bills). Perhaps those subcommittees were more active because either they had more active subcommittee leaders, or they had a larger subcommittee agenda, or they were serving interest groups which felt that their needs were great.

Table 2

House Agriculture Committee Action Taken on Bills Reported to it by its Eight Subcommittees, 98th Congress

Action Taken

Subcommittee

$\begin{array}{cccc}1 & 2 & 3 & 4 \\ \text { Minor } & \text { Notable } & \text { Major } & \text { Bill does } \\ \text { Changes } & \text { Changes } & \text { Changes } & \text { not pass }\end{array}$

Wheat, Soybeans and

Feed Grains

3

0

0

0

3

Conservation, Credit and Rural Development

5

2

0

0

Department Operations,

Research, and Foreign Agriculture 4

Tobacco \& Peanuts

1

Livestock, Dairy, and

Poultry

Cotton, Rice, and Sugar

1

2

Domestic Marketing, Consumer

Relations, and Marketing

4

Forests, Family Farms,

and Energy

6

26

4

0

8

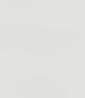


Bills passed to the House by the full Agriculture committee with no record of having been referred to a subcommittee

Total bills considered by the full Agriculture committee during the 98th Congress:

1. Reported out with no or only minor (such as stylistic) changes.

2. Reported out with changes which altered the bill in a notable manner.

3. Reported out with major changes which significantly altered basic thrust of the bill. 4. No record of the bill passing the committee.

Source: Minules of the Business Meetings and Hearings of the Committee on Agriculture, House of Representatives, 98th Congress, U.S. Government Printing Office, Washington, D.C., 1983-5, Four Volumes.

The Agriculture Committee in the 98th Congress. Even a casual reading of Table 2 strongly suggests that bills reported out by House Agriculture subcommittees during the 98th Congress enjoyed a rather welcome reception before the full committee. Of the 38 bills reported in this category, 26, or approximately 68 percent, were subject to only minor changes by the full Agriculture Committee. Moreover, no bills were extensively recast (Type Three) by the full committee. In addition, there does not appear to be any pattern across the subcommittees in comparing how their respective bills were altered by the full committee. The subcommittee winning the passage of the most (six) bills in the minor changes category, Forests, Family Farms, and Energy, also had the most bills die in the full committee. Conversely, those three subcommittees which were the least active in producing legislation also were successful in winning approval of some of their bills.

Comparing the Agriculture Committee in the 95th and 98th Congresses. A useful focus here could be to compare the performance of the committees during each of the terms examined. The House Agriculture subcommittees in the 98th Congress appeared to be much more effective in influencing the policy making process than their counterparts in the 95th Congress. Especially noteworthy is a comparison of the first and fourth categories in the 98th Congress with their counterparts in the 95th. Table Two reports 26 bills in the "minor changes" category compared with only eight in the "bill does not pass" group. However, Table One shows 23 bills in the "minor changes" category while there were 21 in the "bill does not pass" group. Moreover, during the 95th Congress, 31 bills were found to have been reported out to the House by the full Agriculture Committee with no record of having been referred to a subcommittee compared with only four such bills during the 98th Congress. Finally, one should note the large difference in the amount of legislation handled by the two respective committees. During 
the 95th Congress, the House Agriculture committee members considered 82 bills while their counterparts in the 98th considered 42 bills.

The above findings in part provide limited support for a position taken by Smith and Deering which asserted that the ascendancy of subcommittee influence in policy making within constituency committees such as House Agriculture was not initiated immediately following passage of the Subcommittee Bill of Rights. Instead, the influence of these subcommittees gradually expanded over several years. This happened, in part, because there was less pressure by constituency committee members to expand the power of subcommittees than there was by those on policy committees. On Agriculture, there tended to be a consensus among members as to what legislative goals should be sought by the group. And, perhaps more importantly, there was pressure among members to maintain a coalition of interests to assure that each group could win its fair share of benefit (Smith and Deering, 1984, pp. 140-2).

However, despite these factors, constituency committees have tended to evolve farther in the direction of subcommittee goverment than policy committees, for example, Smith and Deering argue. This has tended to happen because constituency committee members are highly likely to join subcommittees whose interest they would like to serve. With this as an obvious prevailing norm, the members are less likely to challenge the turf of other subcommittees. Moreover, policy proposals often are not perceived in zero-sum terms on committees such as House Agriculture, hence members are willing to accommodate policy needs of other subcommittees because it would not appear to threaten the interests of others on the full committee (Smith and Deering, 1984, pp. 144-5).

Finally, there could be at least two reasons why there was such a notable difference in the size of legislative agendas between the House Agriculture committees of the two terms. One obvious reason could be that the 95th Congress passed a farm bill, thus necessitating a rather large influx of activity for the committee. Conversely, the 98th Congress could simply have reflected a trend toward a smaller legislative agenda. One one hand, this could stem from an overall trend toward fewer bills being handled by Congress. On the other hand, it might suggest a possible decline in political strength (and, hence, activity) of agriculture groups in Congress. 
Table 3

\title{
House Judiciary Committee Action Taken on Clean Bills Reported to it by its Seven Subcommittees, 99th Congress
}

\author{
Action Taken
}

Subcommittee

$\begin{array}{ccccc}1 & 2 & 3 & 4 & \mathrm{~N} \\ \text { Minor } & \text { Notable } & \text { Major } & \text { Bill does } & \\ \text { Changes } & \text { Changes } & \text { Changes } & \text { not pass } & \end{array}$

Administrative Law and Governmental Relations

Civil and Constitutional Rights

Courts, Civil Liberties, and the Administration

of Justice

Crime

Criminal Justice

Immigration, Refugees, and International Law

Monopolies and Commercial

$\mathrm{N}$
Law
1

41

22

3

2

2

15

1
2

(1)

(

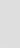

4

1
N

(n)

Bills passed to the House by the full Judiciary Committee with no record of having been referred to a subcommittee

1. Reported out with no or only minor (such as stylistic) changes.

2. Reported out with changes which altered the bill in a notable manner.

3. Reported out with major changes which significantly altered basic thrust of the bill.

4. No record of the bill passing the committee.

Sources: Bill as as printed by the Superintendent of Documents, U.S. Government Printing Office, Washingtan, D.C., 1985-6.

Judiciary Committee in the 99th Congress. Table 3 suggests, contrary to Smith and Deering, that the Judiciary Committee of the 99th Congress behaved largely in a manner similar to the Agriculture Committee in the 98th Congress. Both committees had a majority of their bills coded in Category 1 -about 68 percent for Agriculture and 50 percent for Judiciary. Moreover, the full Agriculture Committee handled only four bills during the 98th Congress while the full Judiciary Committee handled only six during the following two years. In addition, virtually all category four bills for both committees were reported out from their subcommittees near the end of their respective congresses. 
Hence, one could speculate that their failure to pass the full committee stemmed more from the lateness of their arrival from subcommittee than from a rejection by the full panel.

These findings then lead to an additional question. Why were these two panels apparently behaving in a similar manner? A reading of Smith and Deering, as previously noted, suggested that subgovernmenttype behavior would be more prevalent in the constituency-oriented Agriculture Committee. Indeed, this respective positioning was found (as noted above, 68 to 50 percent in Category 1) but not to the degree of polarization one would have expected. Perhaps one solution to the potentially tremendous political pressure surrounding the Judiciary Committee has been to decentralize policy making responsibilities toward subcommittees in a manner like that apparently at work in the Agriculture Committee. However, the reasons behind the behavior of each committee could be entirely different. Agriculture subcommittees could be motivated to serve constituencies while Judiciary subcommittees might be active to avoid political firestorms for their members.

Of special interest is that the major piece of legislation handled by the Judiciary Committee in the 99th Congress was the Ominbus Drug Enforcement, Education and Control Act. The Judiciary Committee shared the highly visible (and possible credit which goes with it) legislation with 11 other standing committees via the joint referral mechanism. It appears that everyone wanted to be seen firing a shot in the war on drugs as the Judiciary's Crime Subcommittee largely handled the committee's contribution to an overall bill which represented the merging of nine others.

\section{Conclusions}

This study appears to support and build upon the work of Deering and Smith, especially when they contend that Congress has been moving in the direction (emphasis theirs) of subcommittee government over the past two decades in the House (Deering and Smith, 1985, p. 189). Moreover, it suggests that both committees appear to be at least moving in the direction of subcommittee government for possibly opposite (yet politically self-serving) reasons. 


\section{References}

Barton, Weldon V., "Coalition Building in the U.S. House of Representatives: Agricultural Legislation," in Cases in Public Policy-Making (2nd Ed.), James E. Anderson, ed.., New York: Praeger, 1982, pp. 100-115.

Davidson, Roger H., "Subcommittee Government: New Channels for Policy Making," in Thomas E. Mann and Norman J. Ornstein, (eds.), The New Congress, Washington: American Enterprise, 1981, pp. 99-133.

Davidson, Roger H. and Walter J. Oleszek, Congress and Its Members (2nd Ed.), Washington: Congressional Quarterly, 1985.

Deering, Christopher J. and Steven S. Smith, "Subcommittees in Congress," in Congress Reconsidered (third edition), Washington: Congressional Quarterly, 1985, pp. 189-210.

Dodd, Lawrence C. and Bruce I. Oppenheimer, "The House in Transition: Partisanship and Opposition," in Lawrence C. Dodd and Bruce I. Oppenheimer, Congress Reconsidered (third edition), 1985 pp. 34-64.

Dodd, Lawrence C. and Richard L. Schott, Congress and the Administrative State, New York: Wiley, 1979.

"Farm Bill Cleared, Puts Government Back in Price Support Arena," Congressional Quarterly Weekly Report, Vol. 35, No. 39, September 24, 1977, pp. 20292032.

Fenno, Richard F. Jr., Congressmen in Committees, Boston: Little, Brown, 1973.

Hall, Richard L. and C. Lawrence Evans, "The Role of the Subcommittee in Committee Decisionmaking: An Exploration," unpublished paper presented at the American Political Science Association annual meeting, New Orleans, August 29-September 1, 1985.

Jones, Charles 0., "The Agriculture Committee and the Problem of Representation," in New Perspectives on the House of Representatives, (2nd ed.), Robert L. Peabody and Nelson W. Polsby, eds., Chicago: Rand McNally, 1969, pp. 155-173.

Minutes of the Business Meeting and Hearings of the Committee on Agriculture, House of Representatives, 95th Congress, United States Government Printing Office, Washington, D.C., 1977-9, four volumes.

Minutes of the Business Meeting and Hearings of the Committee on Agriculture, House of Representatives, 98th Congress, United States Government Printing Office, Washington, D.C., 1983-5, four volumes.

Parker, Glenn R., and Suzanne L. Parker, Factions in House Committees, Knoxville: University of Tennessee, 1985.

Peters, John G. "The 1977 Farm Bill: Coalitions in Congress," in The New Politics of Food, Don F. Hadwiger and William P. Browne, eds., Lexington, MA: Lexington, 1978, pp. 23-35.

Peters, John G., "The 1981 Farm Bill," in Don Hadwiger and Ross Talbot (eds.), Food, Policy, and Farm Programs, Academy of Political Science, Vol. 34. \#3, 1982, pp. 157-73.

Sinclair, Barbara., "The Role of Committees In Agenda Setting in the U.S. Congress," in Legislative Studies Quarterly, February, 1986, pp. 35-45. 
Smith, Steven S. and Christopher J. Deering, Committees in Congress, Washington: Congressional Quarterly, 1984.

Wilson, Woodrow, Congressional Government, Baltimore: Johns Hopkins, 1981. 